\title{
God's Existence and Essence: The Liber de causis and School Discussions in the Metaphysics of Avicenna
}

\author{
Amos Bertolacci \\ IMT School for Advanced Studies Lucca
}

Previous scholarship has emphasized the centrality of chapter VIII.4 of the Ilāhiyyāt (Science of Divine Things, or Metaphysics) of Avicenna's Kitāb al-Šifä (Book of the Cure / Healing) as the main piece of evidence that can be invoked to argue for the dependence of Avicenna's metaphysical thought on the Arabic tradition of Proclus in general, and of the Liber de causis in particular. ${ }^{1}$ Scholars have stressed that this chapter contains the most glaring example of Avicenna's debt towards the Arabic Proclus, in the form that the Proclean Arabic tradition takes in the Kitāb fi Mahd al-Hayr, the Book of the Pure Good, better known as Liber de causis. In other words, to get the best idea of Avicenna's recourse to the Liber de causis in the Ilähiyyāt of the Šifä' (henceforth: Ilāhiyyāt), one has to look at chapter VIII.4 of Avicenna's work. The key-doctrine in this regard is the theory according to which the First Cause or God does not have any essence, since It is only being. This idea, which surfaces in Ilähiyyāt VIII.4, is notoriously expressed in the famous proposition VIII[IX] of the Liber de causis. This proposition marks a "dramatic" departure from the original Proclean and Plotinian tenet of a totally transcendent and unspeakable nature of God, and ascribes to the First Principle a positive nature, namely being. This nature maintains the uninformed or shapeless character of the divine nature already postulated by Proclus, but also holds a precise and intelligible content. ${ }^{2}$ With Ilāhiyyāt viıI.4 and proposition VIII[IX] we are at the doctrinal core, respectively, of Avicenna's magnum opus on metaphysics and of the Liber de causis. With respect to Avicenna, we find in this chapter the fundamental discrimination of Avicenna's cosmos between created beings, on the one hand, and God, on the other, drawn by means of the pivotal distinction of essence and existence in created being

1 The landmark study is D'Ancona 200o, which argues for Avicenna's recourse to the Liber de causis on the basis of evidence primarily taken from Ilähiyyāt viII.4.

2 The relationship of proposition VIII[IX] of the Liber de causis with Proclus is analyzed in Taylor 2020 , with abundant references to all the relevant bibliography. See also the article by Olga Lizzini in the present volume.

(C) KONINKLIJKE BRILl NV, LEIDEN, THE NETHERLANDS, 2022 | DOI:10.1163/9789004501331_012 
and of the lack of this distinction in God, with momentous effects on the entire system of Avicenna's ontology. ${ }^{3}$ With regard to the Liber de causis, the conception of God in terms of being is unanimously acknowledged as the distinctive doctrine of this work.

Against the background of previous studies, I wish to propose here a fresh look to the issue. In fact, further evidence corroborates, on the one hand, but also qualifies in important respects, on the other, the scholarly opinion according to which Avicenna relies on the Liber de causis in Ilähiyyāt viII.4. That Avicenna in chapter VIII.4 is using new and unprecedented sources, which we can identify as, generally speaking, Neoplatonic, can be guessed from the language he uses. More specifically, in the Ilāhiyyāt his employ of the term anniyya (literally "that-ness", in the sense of existence, almost always used by Avicenna in the Ilähiyyāt for God's way of existence) remarkably concentrates in chapterviII.4, which contains nine of its fourteen occurrences. ${ }^{4}$ Albeit not exclusive of the Liber de causis, the term anniyya plays a significant role in this work, and its presence in Avicenna's metaphysical vocabulary can be taken as a sign of Avicenna's attention to this Arabic specimen of Proclean thought, as well as, more in general, to the Neoplatonica araba.

On the side of the necessary refinements of analysis, however, three considerations are in order. First, it should be noticed that Ilähiyyāt viII.4 is a chapter doctrinally multifarious: it presents three distinct theses about God's existence and essence, interconnected through some argumentative cleavages, only one of which shows tight similarity with proposition VIII[IX] of the Liber de causis. Second, Avicenna's account of the relationship between God's existence and essence in chapter VIII.4 bears signs of exegetical concerns on Avicenna's part, evidenced by his frequent first-person interventions in the discussion, which are definitely much rarer, if not absent at all, in other parts of the Ilāhiyyāt, thus suggesting some kind of didactic purposes. Finally, the text of this chapter is variously transmitted in manuscripts, so that the versio vulgata conveyed by the standard Cairo printed edition and by the subsequent printings of the work looks to incorporate textual accretions to the original version of the text: these

3 I have underscored the importance of this passage for a correct understanding of Avicenna's fundamental distinction of essence and existence in Bertolacci 2012, esp. p. 275-277, 282-283. See also Wisnovsky 2005, p. 126-127; De Haan 2020, p. 356-358; Janos 2020, p. 539-550.

4 See Bertolacci 2012a, esp. p. 308. Another occurrence of anniyya falls immediately afterwards, in chapter viII.5, whose topic is tightly linked with that of chapter viII.4, as we are going to see. Also the Latin translator must have been struck by the frequency and concentration of the new ontological terminology of chapter virı.4: whereas he endeavors to translate, as best as he can, the previous occurrences of anniyya in Ilähiyyāt I.1. and I.2, starting with our chapter he resorts to a bare transliteration, anitas, rather than a translation. 
accretions may preserve Avicenna's second thoughts on the issue, or be later interpolations, introduced by members of Avicenna's entourage in the course of school debates, possibly prompted and led by the master himself.

Thus, the doctrinal variety, the authorial interventions, and the philological uncertainty of Ilāhiyya àt viII.4 concur in recommending some caution as to the conclusions that can be likely inferred about Avicenna's effective reliance on the Liber de causis in this chapter.

\section{The Doctrine}

\section{1}

\section{The Main Texts}

The composite nature of the thesis in question should be stressed from the outset. In fact, it is made of two distinct elements: (1) God has no essence; (2) God is only being. These two doctrinal elements should be kept apart, since they receive different formulations in the two works examined here. Previous studies have focused on passages from the Liber de causis and chapter VIII.4 of the Ilāhiyyāt of Avicenna, in which the author of the Liber and the Šayh al-ra'is converge on both (1) and (2) and, on the basis of this evidence, have concluded the probable dependence of Avicenna on the Liber de causis. The selected passages are labelled "NEOB" ("No Essence, Only Being") in what follows. However, equally relevant further passages in the Liber de causis and in the Ilähiyyāt, as we are going to see, complicate the picture about both (1) and (2) and put in question the supposed dependence of the latter work on the former.

Text 1, Liber de causis, prop. VIII[Ix] (ed. Taylor 1981, p. 179.5-180.4): [NEOB] And the intelligence possesses shape (hilya $)^{5}$ because it is being and form (anniyya wa-șüra), and likewise soul possesses shape and nature possesses shape, but the First Cause does not have shape because It is only being (wa-laysa li-l-illati l-ülà hilyatun li-annahā anniyyatun faqaț).

$[\alpha]$ So if someone says: It must have shape, we say: Its shape has no end (hilyatuhā lā nihāyata lahā $)^{6}$ and Its individual [substrate] is the Pure

5 Instead of hilya ("shape"), the reading kulliyya ("universality") —attested by the second hand of ms. Leiden, Universiteitsbibliotheek, Golius 209, fol. 11-is adopted in Bardenhewer 1882, p. 78.8-79.4, and Badawī, p. 12.14-17. The following five instances of hilya in the present passage are corrected into kulliyya in the Leiden manuscript and edited as kulliyya by Bardenhewer and Badawī.

6 Ed. Taylor: hilyatuhā lā nihāyata lahā. Ed. Bardenhewer and ed. Badawī: hilyatuhā lā nihāyatuhā ("Its shape is Its not-endedness" [?]). 
Good (šahșuhà al-hayru al-mahḍu) pouring forth all goods on the intelligence and on all other things through the mediation of the intelligence (English translation in Taylor 1981, p. 299-300, modified). ${ }^{7}$

Text 2, Avicenna, Šifä̀), Ilāhiyyāt VIII.4 (Ibn Sīnā 196o, p. 344.10 [ß]; p. 344.11-12; p. 346.11-12 [Y]; p. 347.10-12 [NEOB]):

[ß] We return [to the previous discussion] and say that the First has no quiddity other than that-ness (al-awwalu lā māhiyyata lahū gayra alanniyyati) $[\ldots]$.

$[\gamma]$ We therefore say that the Necessary Existent cannot have a quiddity to which the necessity of existence necessarily follows [...]. Hence the Necessary Existent has no quiddity apart from the fact that It is Necessary Existent ( fa-lā māhiyyata li-wāğibi l-wuğūdi gayra annahū wāğibu l-wuğúdi), and this is the that-ness (al-anniyya).

[NEOB] Hence the First has no quiddity ( fa-l-awwalu lā māhiyyata lah $\bar{u}$ ), and on the things that have quiddities existence (wuğ $\bar{u} d$ ) emanates from It. Hence It is the Abstract Existent (muğarrad al-wuğūd) with the condition of denying of It non-existence and the other descriptions; then, the other things which have quiddities are possible [entities] which exist through It.

\section{$1.2 \quad$ Basic Convergence}

In the меов passage from Liber de causis, we read that Intellect and Soul are both being (anniyya) and form (șüra) and, in as much as they are form, they possess shape (hilya, literally: "decoration"), whereas the First Cause is only being, and therefore does not have shape. By implication, we also guess that, for the author of the Liber de causis, the First Cause, contrary to Intellect and Soul, does not have form as well, although this is a point not explicitly made

7 In the additional recension of Liber de causis discovered by Thillet and Oudaimah this passage reads as follows: "We say that the intelligence possesses shape when it rises towards the First Cause, since it is being and form, and likewise the soul possesses shape, whereas the First Cause has no shape, since It is a pure being having no shape. The shape of the intellect is that, in order to know, it needs to go back to its essence, otherwise it does not know, whereas the First Cause does not need to go back to Its essence, since It is only cause (liannahā illatun faqaț) and nothing else. So if someone says: the First Cause must have shape, we say: Its shape has not been grasped, that is, it is neither grasped nor attained. Its shape is also the Pure Good pouring forth all goods on the intelligence and all other things through the mediation of the intelligence" (Thillet Oudaimah 2001-2002, p. 345.9-14). The fact that the crucial sentence "the First Cause ... is only being" in Text 1 reads "the First Cause ... is only cause" in this additional recension makes one suppose that Avicenna was not reading the Liber de causis according to this latter recension. 
in the text. The Arabic term anniyya, translated here as "being", has a long history and is variously rendered into European languages: here I adopt for it the meaning of "being" as far as the Liber de causis is concerned, whereas I switch to the translation "that-ness" in the case of Avicenna, for the reasons we are going to see. The term "shape" (hilya) means "formal determination", cisely, "finite complex of qualities and attributes". ${ }^{9}$ Without going deeper into the etymology and usage of these terms, it is easy to guess that for the author of the Liber de causis the term "shape" is closely related and almost synonymic to "form".

In the corresponding NЕOB passage of Avicenna, we find basically the same idea, expressed with a different and more technical terminology. Avicenna contends that the First, namely the First Principle or God, does not have any quiddity (mähiyya), and that It is what Avicenna calls "the Abstract Existent" (muğarrad al-wuğ $\bar{u} d$, lit.: "the abstract with respect to existence"), namely the existent whose existence derives from the abstraction by way of negation of all qualifications that are incompatible with, or additional to, existence (like nonexistence and the descriptions that accrue over the bare fact of existing). ${ }^{10}$

The resulting situation is therefore relatively straightforward: as the Liber de causis contends that the First Cause does not have an essential form and a delimiting shape, but possesses only being, likewise Avicenna states that the First does not have a quiddity, but is an existent whose existence is utmost abstract or pure. The probable dependence of Avicenna on the Liber de causis looks corroborated by a third element shared by both texts, namely the idea of an emanation from the First Cause, conceived in this way, towards inferior things: although the emanation is of goods in the case of the Liber de causis, as we are going to see, of existence in the case of Avicenna, the very idea of emanation is a key common doctrine of both texts. ${ }^{11}$

8 D'Ancona 1995, p. 107 ("détermination formelle").

9 Serra 1975, p. 426-427.

10 The expression muğarrad al-wuğ $\bar{u} d$ (literally: "abstract with respect to existence"), which occurs in Avicenna's Еов passage and in its prosecution in Text 3 below, is translated here as "Abstract Existent" for the sake of brevity, on account of the expression al-mawğ $\bar{u} d$ al-muğarrad posited by Avicenna as equivalent to it in Text 3, and by way of similarity with the conventional translation of wäğib al-wuğūd (literally: "necessary with respect to existence") as "Necessary Existent" in Avicennian scholarship. The expression at stake is translated as "pure existence" in Marmura 2005, p. 276, which is a viable translation, provided that the existent (or the existence) in question is regarded as pure in so far as it is taken apart from superadded qualifications. The abstract or pure nature of God's existence is precisely the result of His lack of a quiddity, and of the ensuing possibility of removing from Him any kind of essential features. 


\section{Liber de causis VIII[IX] Avicenna, Ilähiyyāt VIII.4 (NEOB)}

(NЕОВ)

$\begin{array}{lll}\begin{array}{l}\text { God } \\ \text { (1) has no essence }\end{array} & \begin{array}{l}\text { The First Cause } \\ \text { does not have shape (hilya) } \\ {[\text { or form }(s ̦ u ̈ r a)]}\end{array} & \begin{array}{l}\text { The First } \\ \text { has no quiddity (mähiyya) }\end{array} \\ \text { (2) is only being } & \text { is only being (anniyya) } & \text { is the Abstract Existent (muğarrad al-wuğūd) }\end{array}$

\subsection{Complications}

But if we enlarge the scope of the analysis from the NЕОв passages to other contiguous passages in the same textual units of the Liber de causis and the Ilāhiyya $\bar{t}$, we face with several complications regarding both issue (1) and issue (2). The complications regarding the Liber de causis are basically two: to start with, the First Cause, after having been deprived of any shape in the NЕов passage, in the final lines of proposition VIII[IX] (passage $\alpha$ ) is said to possess a certain type of shape, namely an endless shape. Being endless, this type of shape is likely to amount to no shape at all: nonetheless, it is called shape and attributed to the First Cause. The second problem is that, despite being qualified as only being in the меов passage, the First Cause is also characterized in terms of goodness in passage $\alpha$ : It is pure goodness in itself, and the source of goods for the other realities.

The complications regarding Avicenna are in no way less serious. The NEOB thesis in Ilāhiyyāt VIII.4 is preceded by at least two other stances on the issue $(\beta, \gamma)$. In these previous cases, Avicenna advocates a much more nuanced position about the possess of a quiddity by God, called in one case the First $(\beta)$, in the other case the Necessary Existent $(\gamma)$, this latter being Avicenna's favourite expression to refer to God. In the $\beta$ thesis, the First is said to have no quiddity other than that-ness, this entailing a certain coincidence of quiddity and thatness or existence in God, and, by implication, a certain possess of quiddity by God, in partial contravention of the меов thesis. In the $\gamma$ thesis, by rephrasing the $\beta$ thesis, the Necessary Existent is said to have no quiddity other than being Necessary Existent. In this way, the type of divine existence that coincides with God's quiddity is characterized not only in terms of existence, but also in terms of necessity, so as to transgress the requirement expressed in the мЕ ов passage of denying from the First any feature different from existence. The NEOB thesis is hardly reconcilable with the $\beta$ thesis and the reformulation of this latter in the $\gamma$ thesis: in the Avicennian corpus one can find statements going in either 
TABLE 2 "Complex" Scenario

\begin{tabular}{|c|c|c|c|c|c|}
\hline & $\begin{array}{l}\text { Liber de cau- } \\
\text { sis VIII[IX] } \\
(\text { NEOB) }\end{array}$ & $\begin{array}{l}\text { Liber de causis } \\
\operatorname{VIII}[\mathrm{IX}](\alpha)\end{array}$ & $\begin{array}{l}\text { Avicenna, } \\
\text { Ilähiyyāt VIII.4 } \\
(\beta)\end{array}$ & $\begin{array}{l}\text { Avicenna, } \\
\text { Ilähiyyāt VIII.4 } \\
(\gamma)\end{array}$ & $\begin{array}{l}\text { Avicenna, } \\
\text { Ilähiyyāt vIII.4 } \\
\text { (NEOB) }\end{array}$ \\
\hline God & The First Cause & & The First & $\begin{array}{l}\text { The Necessary } \\
\text { Existent }\end{array}$ & The First \\
\hline $\begin{array}{l}\text { (1) does not } \\
\text { have any } \\
\text { essence }\end{array}$ & $\begin{array}{l}\text { does not have } \\
\text { shape }(\text { hilya }) \\
{[\rightarrow \text { is not form }} \\
(\text { șüra })]\end{array}$ & $\begin{array}{l}\text { has an endless } \\
\text { shape }\end{array}$ & $\begin{array}{l}\text { has no quid- } \\
\text { dity other than } \\
\text { being/that-ness } \\
\text { (anniyya) }\end{array}$ & $\begin{array}{l}\text { has no quiddity } \\
\text { other than being } \\
\text { Necessary Existent }\end{array}$ & $\begin{array}{l}\text { has no quiddity } \\
\text { (māhiyya) }\end{array}$ \\
\hline $\begin{array}{l}(2) \text { is noth- } \\
\text { ing other } \\
\text { than being }\end{array}$ & $\begin{array}{l}\text { is only being/ } \\
\text { that-ness } \\
\text { (anniyya) }\end{array}$ & is the pure good & & $\begin{array}{l}\text { being Necessary } \\
\text { Existent is [its] } \\
\text { being/thatness }\end{array}$ & $\begin{array}{l}\text { is the Abstract } \\
\text { Existent (muğar- } \\
\text { rad al-wuğūd) }\end{array}$ \\
\hline
\end{tabular}

direction, and the issue is debated both in post-Avicennian falsafa and in contemporary scholarship. ${ }^{12}$ The Arabic reception of this chapter of the Ilähiyyāt reinforces this contrast, since some later authors stress Avicenna's adherence to the Nєов thesis (for instance, al-Ġazālī in the Tahäfut al-falāsifa), whereas other authors vindicate by contrast his endorsement of the $\beta$ and $\gamma$ theses (Averroes in the Tahäfut al-Tahäfut). This is really a crucial juncture of Avicenna's metaphysical system and a vexata quaestio of Avicennian scholarship, which deserves a future independent analysis, since the ambivalence at stake might depend not only on doctrinal oscillations on Avicenna's part, but also on his recycling of previous written material in chapter viII.4 of the Ilāhiyya $t^{13}$

For the present purposes the relevant point is that, whereas there is a certain convergence between Avicenna and the Liber de causis on issues (1) and (2) as regards the NЕОв thesis, the accounts of theses $\alpha, \beta$, and $\gamma$ in the two works are sensibly different from one another with respect to both issues. This difference shouldn't be underestimated. The context of chapter VIII.4 makes clear that the $\beta$ and $\gamma$ theses are for Avicenna in no way less important than the NЕOB thesis. To start with, as we have already remarked, they are the first views about God's essence and existence that Avicenna provides in chapter viII.4, and their exposition covers the entire first part of the chapter, after the introductory remarks. The NEOB thesis is expounded much later, at the beginning of

\footnotetext{
12 See Wisnovsky 2005, p. 127-132; Spallino-Panzeca 2019, p. 106-127, and the references to relevant passages of Avicenna's works and to contemporary studies in Bertolacci 2012, p. 276, n. 26 .

13 I have touched upon this issue in Bertolacci 2017 a.
} 
the last part of chapter viII.4, in which Avicenna provides a systematic account of negative theology: from the fact that God does not possess quiddity at all, Avicenna argues that God does not have genus, specific difference, definition, and demonstration, and that He is not a substance. In this way, the total negation of the possess of quiddity in the лЕОв passage is the starting-point and the theoretical foundation of this specimen of theologia negativa, which continues after chapter VIII.4 until the end of chapterviII.5. Despite its contextual relevance, as a trait d'union between two distinct chapters of the Ilähiyyāt and as the doctrinal basis of the negative theology expounded there, however, the NЕОв thesis is not Avicenna's first stance on the issue, this latter being rather the $\beta$ and $\gamma$ theses. Moreover, Avicenna provides a lengthy and articulated argumentation for the $\beta$ and $\gamma$ theses, according to his usual mode of proving a tenet, namely by distinctions of possible cases, reductiones ad absurdum etc. The NЕOB thesis somehow surreptitiously surfaces in this argumentative context, as the unexpected conclusion of a proof that, judging from its starting-point, was meant to corroborate the $\beta$ thesis. Thus, properly speaking, no independent proof of the NЕOB thesis is given.

Chapter VIII.4 is based on these two complementary and self-standing sections: the carefully proved $\beta$ and $\gamma$ theses, on the one hand; the unproved $\mathrm{NEOB}$ thesis and the negative theology ensuing from it, on the other. None of them totally prevails over the other, and the transition between them remains a shadowy point of Avicenna's thought. ${ }^{14}$ As we are going to see in the following two parts, what immediately precedes the NЕОВ thesis (that is, the argumentations in support of the $\beta$ thesis) and what immediately follows it (i.e., the explanation of the way in which God is the Abstract Existent) increase the uncertainty: in both places, what we presently read in the Cairo edition might be a reworking of Avicenna's original text, in the form of later interventions by Avicenna himself (first-person explanations), or of textual integrations by him or by his school (an alternative version of the $\beta$ thesis).

\section{$2 \quad$ First-Person Authorial Explanations}

The formulation of the NЕOB thesis in Ilähiyyāt viII.4 (see above, Text 2) is followed by a very special exegesis of Avicenna's text, in as much Avicenna himself takes the frontstage and speaks in first person, providing his own explanation

14 In general, chapter viII.4 presents signs of a painstaking composition, in which Avicenna, in the course of a few lines, inserts digressions ("We return [to the previous discussion]", wa-na'üdu, p. 344.10), and has second thoughts on the matters discussed ("We rather say, starting anew", bal naqūlu min ra'sin, p. 344.12). 
of what he has stated immediately before. To this end, within a few lines, he explains a sentence of the лЕов thesis by means of two expressions at the first singular person ("The meaning of my statement", ma'nà qawli, p. 347.12; "I mean about [the First]", a ni fi [l-awwali], p. 347.14) not attested elsewhere in the Ilāhiyyāt.

Text 3: Avicenna, Šifằ, Ilāhiyyāt viII.4 (Ibn Sīnā 196o, p. 347.12-15):

The meaning of my statement "It is the Abstract Existent, with the condition of denying of It the other additional [descriptions]" (mánà qawlī innahū muğarradu l-wuğūdi bi-šarți salbi sā̉iri l-zawā̇idi 'anhu) is not that It is the absolute comparticipated existent (al-mawğūd al-muțlaq al-muštarak fihi), ${ }^{15}$ if ever an existent having this attribute may be. For this [other existent] would not be the Abstract Existent (al-mawğüd almuğarrad) with the condition of denying, but the existent without the condition of affirming.

I mean about the First (a'nifi l-awwali) that It is the existent with the condition of not adding composition [of further descriptions with existence], whereas this other [existent] is the existent without the condition of [this] addition. For this reason, [the existent] that is universal $(k u l l i \bar{l})$ is predicated of all things, whereas that [Abstract Existent] is not predicated of what has addition, ${ }^{16}$ and everything other than It has addition.

Cases of "authorial self-exegesis", conveyed by terms stemming from the Arabic root "to mean" ('-n-y), are not limited to this passage or to chapter viII.4, and can be found also elsewhere in the Ilähiyyāt. With respect to the rest of the Ilähiyyāt, however, chapter viII.4 represents a remarkable case from various points of view. First, it displays a noteworthy concentration of Avicenna's standard self-explanations at the first plural person, in line with the sort of $p l u$ ralis maiestatis that he normally adopts in this chapter as well as elsewhere in the Ilähiyyāt: at least four such cases can be found in Ilähiyyāt viII.4, as it is printed in the standard Cairo edition, both before and after the explanation at

15 The reading al-wuğūdu al-muțlaqu in Ibn Sīnā 196o has to be corrected in al-mawğūdu almuțlaqu attested by mss.: Oxford, Bodleian Library, Pococke 125; Oxford, Bodleian Library, Pococke 110; and Leiden, Universiteitsbibliotheek, Or. 4-also on account of the reiterated occurrences of the term mawğüd in the immediately following lines (cf. Bertolacci 2006, p. 535). For further information on these and the other manuscripts of Avicenna's Ilāhiyyāt quoted in the present contribution, see PhiBor 2014-2019.

16 The reading wa-dālika lā yuḥmalu 'alà kulli mā hunāka ziyādatun in Ibn Sīnā 196o has to be corrected in wa-d̄âlika lā yuhmalu 'alà mā hunāka ziyādatun on the basis of a closer inspection of the manuscript evidence (cf. Bertolacci 2006, p. 535). 
the first singular person ("Know that when we say (...) we do not mean (...)", wa-

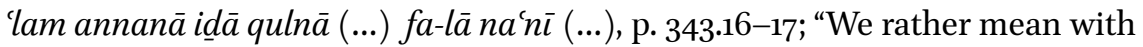
our statement (...) that (...)", lākinnā na'nì bi-qawlinā (...) annahü (...), p. 344.34; "The meaning of our statement (...) is (...)", wa-ma'nà qawlina $(. .)$, p. 347.4; fa-qawlinā (...) ma'nāhu (...), p. 348.18-349.1). Second, Avicenna's explanations expressed in the first singular person in Text 3 ("my statement", "I mean about") are hapax legomena in the work. ${ }^{17}$ Third, many of the points explained by Avicenna in chapter VIII.4 by means of these formulas (both at the first plural and at the first singular person) are entire sentences of his discourse ("statement", $q a w l)$, rather than single terms and concepts, as it is usually the case in the rest of the Ilāhiyya at. In Text 3 , for instance, Avicenna repeats almost verbatim a statement shortly preceding ("It is the Abstract Existent, with the condition of denying of It the other additional [descriptions]"), and takes care of clarifying what he means by providing its interpretation ("I mean about the First etc.").

In general, the high density of self-explanations, of different styles (first singular person; first plural person) and scopes (lemmatic; terminological), in chapter VIII.4 is remarkable, since it represents a unique case in the Ilāhiyyāt. Moreover, the explanations at the first singular person in Text 3 are connected with a doctrine and an expression that are equally exceptional, since they occur only here and nowhere else in the Ilähiyyāt: the expression is "Abstract Existent" (muğarrad al-wuğūd), which, independently from its reference to God, can be found uniquely in Text 3 . Though brief and cursory, Text 3 faces a fundamental issue. In fact, this passage shows a polemical intent by Avicenna, definable, broadly speaking, as "anti-Platonic": Avicenna is very carefully distinguishing the kind of existent he is speaking of here, which is devoid of any feature other than existence and is obtained by abstracting all possible further characterizations from its basic existence, from the notion of an existent whose existence is shared by all the concrete existents through participation, being in this way not dissimilar from a Platonic form. Avicenna calls this second type of existent "the absolute existent in which there is participation" (al-mawğudu al-muțlaqu al-muštaraku fihi): whereas the Abstract Existent that he proposes rests on the condition that all attributes other than existence are denied of

17 The expression "my statement" (qawlī) occurs only in this passage of the Cairo edition of the Ilāhiyyāt. Whereas the expression "I mean" ( $\left.a^{c} n \bar{\imath}\right)$ —used both as a bare equivalent to "that is" with a direct object, and as a more technical explanatory device ("By x I mean y", a'nī bi- etc.) —is more frequent (see, for instance, viII.1, p. 328.13; Burhān IV.4, p. 290.1; IV.10, p. 333.4), the present passage is the only attested occurrence of the phrase "I mean about $\mathrm{x}$ that it is $\mathrm{y"}$ (a'nīfi etc.) in the Ilähiyyāt. A sentence "I don't mean ... I rather mean" (lastu a'nī ... bal a'nī) occurs in Nabāt 4, p 15.18-19. 
It, this absolute existent in which there is participation rests on the opposite condition that nothing besides existence is affirmed of it: had this existent a positive feature joined with its existence, it could not share its existence with the concrete existents that do not possess that specific feature and, as a result, it could not be the target of participation in an absolute way by all existents. ${ }^{18}$ The fundamental divide between an "Aristotelian" and a "Platonic" way to the First Principle that Avicenna is facing in Text 3 justifies the great attention he pays to explaining himself as best as he can and to avoiding any possible misunderstanding. The reason why he resorts only in this case to explanations introduced by formulas at the first singular person remains, however, obscure. This shift to a different style of explanation may suggest that Text 3 belongs to a layer of the composition history of chapter viII.4 different from that of the rest of the chapter.

A possible further occurrence of the same explanatory attitude analyzed here should attract our attention next, since it arguably points to another case of textual stratification. This explanation is attested by some manuscripts of the Ilähiyyāt not considered in the Cairo edition, as well as by the indirect tradition of the work, at the beginning of another crucial passage of chapter viII.4, namely the proof that Avicenna provides of the $\beta$ thesis. Significantly, this time the explanation in question is expressed in a third way, different from the previous two just recalled.

18 Several factors concur to characterizing the position opposed here by Avicenna as large loquendo "Platonic" (at least to his eyes). First of all, the opposition abstraction vs. participation regarding the two types of existent calls to mind generally speaking the polarity between an Aristotelian and a Platonic approach to the issue. Second, the final reference to the existent in which there is participation as "universal" (kulli) sounds like a further resumption in the Ilāhiyyāt of Avicenna's polemic against the Platonic ideas considered as universals, already proposed in chapters V.1-2 and viI.2-3 (where the ideas are explicitly called "Platonic models"); Avicenna's doubt in our passage on the possibility that the existent in which there is participation can actually be found in reality ("if ever an existent having this attribute may be" he says) goes in the same direction. Finally, our NEOB passage is close to Avicenna's resumption of the eleventh aporia of Book Beta of Aristotle's Metaphysics at the start of our chapter viII.4, whose target in Aristotle (and, on his footsteps, in Avicenna) is precisely the Platonic account of Being and One (Bertolacci 2004). A conception of the First Principle as pure being is variously attested in the Platonic tradition, as in Numenius of Apamea in the II c. AD (see on this Leinkauf 2002; I wish to thank an anonymous referee for having brought this point to my attention). 


\subsection{A Suspect Duplication of Proofs of the $\beta$ Thesis}

As already remarked, in Ilähiyyāt viıI.4 Avicenna provides arguments for the $\beta$ and $\gamma$ theses, whereas he simply states the NЕов thesis. A fundamental step of Avicenna's argumentation in favour of the $\beta$ thesis is to show that all realities whose quiddity is not coincident with existence are caused, so that God, being uncaused, cannot have a quiddity distinct from existence. In the Cairo edition, the $\beta$ thesis is first announced and later argued. The argumentation unfolds in a context, however, which is anomalous in more than one respect. First, the formulation of the $\beta$ thesis to be proved (p. 344.10) precedes at long distance its proof (p. 346.13-347.15), from which it is separated by the formulation and proof of the $\gamma$ thesis. ${ }^{19}$ Second, the proof in question is two-fold, in so far as a main argument for the $\beta$ thesis is preceded by a similar shorter, but incomplete, argument: the two arguments share topic, way of argumentation, and terminology, but are independent from one another and can be regarded as two proofs of the same tenet. Besides consisting of two similar arguments instead of one, the overall proof runs with the first, incomplete argument coming before the second, complete one. Finally, the proof of the $\beta$ thesis by means of these two arguments ends with a conclusion which is phrased in NEOB terms and turns out to be the aforementioned NЕов thesis, rather than the $\beta$ thesis.

These two proofs of the $\beta$ thesis are interesting in several ways. To start with, they mark the transition from the $\beta$ thesis to the NEOB thesis, since they are Avicenna's last words on the $\beta$ thesis before the abrupt irruption of the NЕОв thesis into the scene. In this way, they fall at a crucial juncture of chapter viri.4. To prove the $\beta$ thesis, Avicenna argues that existence, being distinct from essence or quiddity, necessarily follows this latter either on account of the quiddity itself, or on account of something else, namely a cause. Now, it is impossible that it follows the quiddity on account of the quiddity itself, since the quiddity, in order to be followed by existence, should already exist. What remains is that existence follows the quiddity on account of something else, i.e. the cause of existence, which shows that everything whose existence is distinct from quiddity is caused. The expected conclusion of this argumentation, on the basis of its starting point ("everything whose quiddity is other than that-ness is caused" in the second proof) would be that the First, in so far as it is not caused, has

19 The interposed part itself is not totally straightforward: the formulation of the $\gamma$ thesis ("We say", fa-naqūlu, p. 344.11-12) is separated from its proof ("We say", fa-naqūlu, p. 345.6346.12 ) by an intermediate discussion introduced by the sentence "We rather say anew" (bal naqülu min ra’sin, p. 344.12-345.5). 
no quiddity other than that-ness or existence, in line with the $\beta$ thesis that the proof was meant to corroborate. In fact, however, the proof ends with an unexpected and unjustified conclusion formulated in NEOB terms, namely that the First has no quiddity (at all) and that It is (only) abstract existence. This shift, as signaled above, represents the most relevant doctrinal oscillation of the chapter.

Moreover, the two proofs convey the idea that existence is an accident of quiddity, being the only place of Avicenna's Ilāhiyyāt in which terms belonging to the Arabic root meaning "accident" ( $\left.{ }^{c}-r-d\right)$ are used to express the relationship between existence and essence. The issue of the accidentality of existence with regard to essence will assume central importance in the later reception of Avicenna's philosophy, for example in the anti-Avicenna polemics by Averroes on this point, and the two proofs at hand provide fundamental evidence on the issue in Avicenna's masterpiece on metaphysics. ${ }^{20}$

A third reason of interest is that the first proof turns out to be a partial duplicate of the second main proof, with the possibility of being a later interpolation having explanatory aims. The shorter first proof, although it comes before the second one, hardly stands alone. It is acephalous, since it does not state the thesis to be proven. Moreover, it is truncated, i.e. it argues only for one ([i]) of the two sides of the distinction on which it is based ([i], [ii]), and displays no explicit conclusion, which can only be guessed.

The text of the first proof, as presented in the Cairo edition, does not fit its context. Especially the incipit of this passage, as reported in Table 3, is problematic. The main reason to doubt its soundness is the counterfactual initial hypothesis "if that-ness and existence were two things that occur accidentally" (al-anniyya wa-l-wuğūd law șārā 'äriḍayni). In fact, from a premise like this, assuming that the first proof agrees with the second not only about point [i] but also about point [ii], the following line of reasoning ensues: "If that-ness and existence were accidents of the quiddity, they would belong to the quiddity on account of a cause. But they are not accidents. Therefore, they do not belong to the quiddity on account of a cause". However, the conclusion of this modus tollens goes against Avicenna's intention, as it is manifested by the sec-

20 In Bertolacci 2013, p. $255^{-259}$, I have documented that, whereas Ilähiyyät viII.4 is the only place of Avicenna's work in which Avicenna portrays the relationship between existence and essence in terms of the accidentality of the former with respect to the latter, the Latin translator of the Ilähiyyāt resorts frequently to the verb accidere and the related noun accidens to express this same relationship also in front of other Arabic roots, thus justifying and reinforcing to the eyes of the Latin readers of the work the charge that Averroes addresses to Avicenna precisely on this point. 


\title{
Formulation of the $\beta$ thesis ( $p$. 344.10)
}

We say that the First has no quiddity other than that-ness (anniyya)

\author{
First Proof of the $\beta$ thesis (as in the Cairo \\ Second Proof of the $\beta$ thesis (p. 346.15-347.15) \\ edition, p. 346.13-15)
}

We say (wa-naqūlu inna):

We say (wa-naqūlu inna): everything having a quiddity other than that-ness is caused.

if that-ness and existence were two things

For you know that that-ness and existence, with that occur accidentally (al-anniyya wa-lwuğūd law șārā 'āriḍani) to the quiddity,

regard to the quiddity that is external to thatness, do not have the status of a constitutive entity, but are among the inseparable concomitants (allawāzim) [of the quiddity].

then either [i] they would accompany inseparably it [the quiddity] (yalzamuhā) Therefore, either [i] they accompany inseparably (yalzamu) the quiddity because it is that [given] on account of the [quiddity] itself, or [ii] on account of something external. quiddity, or [ii] their accompanying inseparably it (luzūmuhā) happens because of something [else].

The meaning of our expression (ma'nà qawlinā) "accompanying inseparably" (luzūm) is "following the existence",

and an existent will follow only [another] existent.

[i] But it is impossible that [this] happens on account of the quiddity itself,

[i] Therefore, if that-ness follows the quiddity and accompanies inseparably it on account of [the quiddity] itself, then that-ness, in its existence, will follow [another] existence;

since what follows [something else] follows but everything that follows in its existence only [something] existent; [another] existence, follows something that exists per se beforehand;

it will ensue (yalzamu), therefore, that the quiddity would have existence before its therefore, the quiddity will exist per se before its existence, which is contradictory. existence, which is impossible. 
TABLE 3 Formulation and Proofs of the $\beta$ thesis (cont.)

$$
\text { Formulation of the } \beta \text { thesis (p. 344.10) }
$$

We say that the First has no quiddity other than that-ness (anniyya)

\author{
First Proof of the $\beta$ thesis (as in the Cairo Second Proof of the $\beta$ thesis ( $p .346 .15-347.15)$ \\ edition, p. 346.13-15)
}

[ii] It remains that existence belongs to it [the quiddity] from a cause.

Therefore, everything that has a quiddity is caused.

The rest of the things, other than the Necessary Existent, have quiddities. And it is these quiddities that in themselves are possible in existence, existence occurring accidentally ( $y a^{\prime}$ ridu $u$ ) to them externally.

[Expected $\beta$ conclusion: Hence the First has no quiddity other than that-ness]

[Actual NEOB conclusion] Hence the First has no quiddity, and on the things that have quiddities existence ( $w u g \bar{g} \bar{u} d)$ emanates from It. Hence It is the Abstract Existent etc. (see Text 2, above)

ond proof, since the uncausedness of that-ness and existence squarely contradicts the doctrinal point that Avicenna makes in the second proof, i.e. their causedness. ${ }^{21}$ Accordingly, the part of the second proof corresponding to this counterfactual hypothesis in the first proof is categorical and not hypothetical ("... that-ness and existence, with regard to the quiddity that is external to that-ness, do not have the status of a constitutive entity, but are among the inseparable concomitants [of the quiddity]"), an assertiveness corroborated by the retrospective reference to a previous place of the Ilähiyyāt in which the tenet in question has been established ("For you know that (...)", possibly a ref-

21 From the syntactical point of view, a counterfactual hypothesis of this kind construed with a law not followed by a $l \bar{a}-$, but by a $f a-$, might also look suspicious. 
erence to the locus classicus of Ilähiyyāt I.5). The Cairo text of the first proof is hardly retainable as it is.

Another peculiarity of the first proof with respect to the second one is the emphatic occurrence of the issue of accidentality of existence at the beginning of the first proof (that-ness and existence as "two things that occur accidentally", 'aridayni, to the quiddity), in comparison with its soberer appearance at the end of the second proof ("existence occurring accidentally (...)", ya'ridu, to the quiddity). In this respect, the first proof takes a much more explicit stance than the second does about a crucial and debated issue of Avicenna's ontology, within a general context of the proofs in which the notion of "accompanying inseparably" ( $\operatorname{root} l-z-m)$ is deputed to express-in typical Avicennian terms - the existence-quiddity relationship, as it is the case also elsewhere in the Ilāhiyyāt. ${ }^{22}$

In the following sections, we will see alternative ways of reading the text and understanding the function of this elliptic and problematic first proof.

\subsection{The First Proof of the $\beta$ Thesis: Manuscripts}

The first proof is transmitted in various forms in the manuscript tradition of the Ilāhiyyāt, many more than the scanty apparatus of the Cairo edition suggests. The manuscript tradition investigated to date offers various alternatives to the Cairo text. One of them is radical, in the sense that in a sample of ancient manuscripts and in a valuable witness of the Ilāhiyyāt as its Latin medieval translation the first proof is completely omitted. If the omission did not occur for mere mechanical reasons (both the first and the second proof in the Cairo edition start with the same sentence "We say", naqūlu inna, so as to allow an omission by homeoarchy), we can take it as a possible indication that this passage was originally lacking in Avicenna's text.

In the manuscripts which do not omit the proof, the crucial initial phrase "We say: if that-ness and existence were two things that occur accidentally" (wa-naqūlu inna al-anniyyata wa-l-wuğūda law șārā 'āridayni) is transmitted in three main other ways. Either it is introduced by the same verb "We say" printed in the Cairo edition, with some modification ("We rather say", bal naqūlu, and the like), followed by a sentence which is categorical affirmative, rather than

22 One wonders whether the stress on the accidentality of that-ness and existence at the beginning of the first proof may explain the presence of the counterfactual law in the Cairo text of it: if it can be proved that the reading law is a corruption of the original text of this passage, a reasonable guess would be that the corruption originated by the agency of someone who grasped the problematic character of the accidentality at stake and wanted to smooth it. 
hypothetical ("We say: that-ness and existence are things that occur accidentally", wa-naqūlu inna al-anniyyata wa-l-wuğūda 'āriḍāni) ${ }^{23}$ Or it has no introductory clause at all (be it "We say" or other). Or, most interestingly for the present purposes, it is introduced by the exegetical clause "Its/His meaning is that (...)" (ma'nähu anna), which counts as a third type of exegetical device in chapter VIII.4, this time in the third singular person. This exegetical prop, in its turn, in the various manuscripts which report it, either precedes a hypothetical sentence like the one we find in the Cairo edition, or a categorical affirmative sentence like the one just recalled, or other types of sentences.

This chaotic divergence of readings requires, of course, an independent analysis, which cannot be provided here. Provisionally, we can notice that both the omission and the various versions of the text of the first proof recalled above are attested by very ancient witnesses of the work, so that the genesis of our proof, if it is not the result of the author's intervention, is to be placed very high in the transmission history of Avicenna's Ilähiyyāt. For sure, the recurrence of exegetical motives also in a part of the manuscript tradition of this locus vexatus is worth emphasis, as a further attestation of interpretative concerns in our chapter, be they by Avicenna or by others. The indirect tradition of the Ilāhiyyāt opens the interesting possibility that, at least in this specific case, Avicenna's immediate disciples and circle of scholars may be part of the story.

\subsection{The First Proof of the $\beta$ Thesis: Indirect Tradition}

The earliest readers and receptors of Avicenna's Ilāhiyyāt do not provide homogeneous information about the first proof of the $\beta$ thesis. No evidence of it can be found in Bahmanyār Ibn al-Marzubān (d. XI c.), who posits a very succinct resumption of this part of chapter viII.4 in his Kitāb al-Tahșill. ${ }^{24}$ Likewise, neither al-Ġazālī (d. 1111) nor Averroes (d. 1198) report the proof in their refutations of Avicenna's philosophy. By contrast, a second-generation disciple of Avicenna, al-Lawkarī, who lived between the eleventh and the twelfth

23 This is the reading attested by the two most ancient complete manuscripts of the Ilähiyyāt presently known (Najaf, Maktabat al-Imām Amīr al-Mu'minīn, 3070, fol. 1108-9; Tehran, Kitābhānah-i Millī Malik, 1085, p. 250.7-8; a facsimile edition of the latter is available in Bertolacci-Dadkhah 2019), as well as by other codices. I have adopted this reading in Bertolacci 2012, p. 282 ("We say: that-ness and existence are two things that occur accidentally to the quiddity"), and in my Italian translation of the Ilähiyyāt (Bertolacci 2007, p. 647; cf. Bertolacci 2006, p. 535) on the basis of ms. Oxford, Bodleian Library, Pococke 110.

24 Abū l-Ḥasan Bahmanyār Ibn al-Marzubān (d. 458/1066; the earlier date of 430/1038 is also given), Kitāb al-Tahṣ̂ll, ed. M. Muțahharī, Tehran 1349/1971; 2nd printing, Intišāāāt-i Dānišgāh-yi Tihrān, Tehran 1375Hš/1996, p. 570.11-13. 
century, gives us valuable information on this proof. ${ }^{25}$ In a work in which he quotes massively Avicenna's $\breve{S}_{i f a}{ }^{\prime}$ (Bayān al-haqq bi-damān al-șidq, Clarification of the Truth with the Guarantee of the Veracity), ${ }^{26}$ al-Lawkari transmits a further account of our proof, which he apparently takes verbatim from his source. His Bayān al-Haqq is coeval to the most ancient manuscripts of Avicenna's work presently known.

Text 4: Abū l-Abbās Faḍl Ibn Muhammad al-Lawkarī (V-VI/XI-XII c.), Bayān al-ḥaqq bi-damān al-șidq. Al-Qism al-ilāhī, ed. I. Dībāğī, Tehran 1995, p. 286.3-6:

Explanation (tafsìr) - Its/His meaning is that (ma'nāhu anna), since thatness and existence come [to belong] to the quiddity (al-anniyyata wa-lwuğūda lammā [?] șâra li-l-māhiyyati), then either [i] they accompany inseparably it [the quiddity] on account of the [quiddity] itself, or [ii] on account of something external. [i] But it is impossible that that [this] happens on account of the quiddity itself, since what follows [something else] follows only [something] existent; it will ensue, therefore, that the quiddity would have existence before its existence, which is impossible.-End of explanation (tamma l-tafsir).

This passage is clearly a quotation of our first proof, not only on account of the similarity of the content, but also because in the Bayann al-haqq the reported passage is immediately preceded and followed by al-Lawkarīs report of what precedes and what follows the first proof in the Cairo edition. In other words, al-Lawkari is quoting our proof in the framework of a context identical to the one conveyed by the Cairo edition, within a chapter of the Bayān al-haqq which, from its title until its last line, is the mirror image of Ilähiyyāt viII.4. The wording of al-Lawkari’s report presents problems of its own, which cannot be solved here, and the reading proposed above is my tentative reconstruction of a problematic passage. ${ }^{27}$ The causal sentence proposed ("since that-ness and

25 Marcotte 2006, p. 133-157; Janssens 2012.

26 Abū l-'Abbās Faḍl Ibn Muḥammad al-Lawkarī, Bayān al-ḥaqq bi-ḍamān al-șidq. Al-Qismalilāhī, ed. I. Dībāğī, Tehran 1995 (also published in Islamic Thought. Series of Texts Studies and Translations. II, [International Institute of Islamic Thought and Civilizations] Kuala Lampur n.d.). Prior to the section of metaphysics, also the section of logic of this work has been edited: Bayān al-Haqq bi-damān al-șidq (Clarification of the Truth with the Guarantee of the Veracity). Al-Manțiq 1, al-Madḩal, ed. I. Dībāğ̄i, Tehran 1986 (also published in Islamic Thought. Series of Texts Studies and Translations. II, ISTAC [International Institute of Islamic Thought and Civilizations], Kuala Lampur 1993-1994).

In the Introduction of the Logic section, p. 107-108, three manuscripts of the work are 
existence come [to belong] to the quiddity") provides an interesting way-out of the riddles of the puzzling hypothetical law șāra clause printed in the Cairo edition, but remains provisional, in the wait that future research may give final assessment to this crucial passage of al-Lawkarì's work and of the Ilāhiyyāt. Another difference with respect to the text of the first proof as it is printed in the Cairo edition is the absence of the participle "things that occur accidentally" ('äridayni) as a qualification of that-ness and existence when they are said to belong to the quiddity in the initial sentence. ${ }^{28}$

These problems apart, and most importantly for the present purposes, alLawkari's report of the proof corroborates the existence of an early tradition in which the proof is introduced by the explanatory formula "Its/His meaning is that (...)" (ma'nāhu anna). The fundamental issue is: as regards this formula, shall we understand "Its meaning" or "His meaning", both in this passage of the Bayān al-haqq and in the manuscripts of the Ilähiyyāt mentioned above? In other words, does the pronominal suffix - $h u$ in the expression ma'nāhu mean "its", namely the meaning of a statement of Avicenna, or "his", namely Avicenna's intended meaning? In Arabic, both possibilities are open. In the former case, Avicenna himself might have originated this explanation, whereas in the latter case we could imagine some early readers of the proof (most probably Avicenna's own disciples) as authors of the explanation.

The understanding "its" might represent a third version of the self-explanations by Avicenna noticed above (section 2), some of which are expressed in the first plural person by way of pluralis maiestatis, some others in the first singular person. In this possible third instance of Avicenna's self-explanation, Avicenna would not underscore the authorial nature of the explanation, and would refer

mentioned: ms. Tehran, Kitābhānah-i Markazī-yi Dānišgāh-i Tihrān 250 (siglum ص [Ṣ]); ms. Tehran, Kitābhānah-i Dāniškādah-i Ilāhiyyāt-i Dānišgāh-i Tihrān 695D (siglum ت [T]); and ms. Tehran, Kitābḩānah-i Mağlis-i Šūrā-yi Islāmī 4081 (siglum س [S]). In all of them, Text 4 presents the reading لمار صار (lin replacement of which I propose the reading لمار (lammā șāra). The manuscript reading لمار might be read as an interrogative clause (li-ma șāra), "for what reason did/do [that-ness and existence] come [to belong to the quiddity]?", which is however hardly affordable in the syntactic context of Text 4. The clause that one reads in the current edition of Lawkarìs work remains obscure to me as to its precise morphology and meaning, and I tend to regard it as a misprint. The reading لم صارا (dual form of the verb) can be found in some manuscripts of the corresponding passage of the Ilāhiyyāt (ex. gr. ms. Iran, Rasht, Kitābhāanah-i Millī (form.: Kitābhuānah-i 'Umūmī-yi Ğamciyyat-i Kitābhuānah-i Našr-i Farhang), 37, p. 307.2). I am grateful to Mohammad Javad Esmaeili for having shared with me images of the above mentioned manuscripts of the Bayān al-Haqq.

28 The same absence of 'äridayni can be noticed in some manuscripts of the Ilāhiyyāt: ex. gr. Oxford, Bodleian Library, Pococke 125, fol. $349^{\mathrm{r}}$. 
to his own statement directly and neutrally, without emphasizing that his statement is at stake. On the other hand, the absence of authorial emphasis in the present case (i.e. the lack of Avicenna's references to himself, either in the first singular or first plural person) is compatible with an explanation made by someone other than Avicenna. This second line of interpretation is the only viable, of course, if we adopt the understanding "his", paving the way to Avicenna's disciples as authors of the gloss. The manner in which al-Lawkarin introduces and concludes his quotation of Text 4 sheds further light on this issue.

\subsection{The First Proof of the $\beta$ Thesis as a Complement of the Second Proof}

Al-Lawkari's way of quoting the first proof of the $\beta$ thesis in Text 4 is worth noticing. In the current printing of the Bayān al-haqq, this proof is presented as an "explanation" (tafsir): two occurrences of this term mark both the beginning and the end of al-Lawkarì's report of the portion of the Ilāhiyyāt that hosts the first proof. ${ }^{29}$ In this way, al-Lawkari emphasizes the exegetical character of this proof, already conveyed by the formula "Its/His meaning is that (...)" that he finds at the beginning of this proof in the manuscript of the Ilähiyyāt from which he quotes, without adjudicating whether this alleged gloss is made by Avicenna himself or by someone else. What is sure is that al-Lawkarī does not adopt a similar device for any explanation provided by Avicenna in Ilāhiyyāt VIII.4, and by encapsulating the present passage within the two mentions of "explanation", he secludes it as a sort of "para-text".

The most likely reference of this para-text is the part of chapter viII.4 immediately following Text 4 both in the Bayān al-haqq and in the Cairo edition of the Ilähiyyāt (VIII.4, p. 346.15-347.9), namely the second proof of the $\beta$ thesis, of which it represents a shorter version, as we have seen. The elliptic nature of the first proof and its partial coincidence with the second proof, documented above, allows the supposition that the former is an integration of the latter. ${ }^{30}$ A confirmation of this supposition comes from a synopsis of the two proofs. Albeit similar in structure, terminology, and purport, the two proofs show significant doctrinal differences. The most relevant one regards the principle upon which the two proofs rest: in the second proof, this principle is expressed as

29 The reading tafsìr, printed in the edition of the Bayān al-haqq, is clearly spelled by ms. Ș both at the beginning and at the end of the present passage. Ms. T appears to read tagayyur ("modification") in both places (the apparatus of the edition wrongly reports ta'ayyun in the second place). Ms. S looks to read fa-fassara ("He commented") or tagayyur at the beginning, and tafsir or tagayyur at the end.

30 What precedes Text 4 in the Bayān al-ḩaqq, by contrast, as in the Ilāhiyyāt, is a lengthy argumentation in support of the $\gamma$ thesis, which does not bear any tight relationship with the first proof of the $\beta$ thesis in Text 4 . 
"an existent will follow only [another] existent" or "everything that follows in its existence [another] existence, follows something that exists per se beforehand", whereas in the first proof it is "what follows [something else] follows only [something] existent". As formulated in the second proof, with its emphasis on the existence both of what follows and of what is followed, the principle is surely efficacious, since it leads to the absurd conclusion that the quiddity, in order to be followed by that-ness and existence, must exist beforehand, but it is somehow problematic, since it implies that that-ness and existence, in so far as they follow the quiddity, are existents and bearers of existence themselves, with the frightening possibility of a regressus ad infinitum in existence on their side. ${ }^{31}$ In this respect, the first proof simplifies and smooths the argument of the second, in so far as it puts the requirement of existence only on the side of what is followed (i.e quiddity), not on the side of what follows (i.e. that-ness and existence).

But if this is really the case, i.e. if the first proof is actually meant to complement the second, we would then be in front of an integration somehow "out of place", which precedes, rather than following, the text it is meant to join, both in the Bayān al-haqq and - if we trust al-Lawkarìs report-in the Cairo edition of the Ilāhiyyāt. Such a misplacement can most easily be accounted for on codicological grounds. Different scenarios can be envisaged. We can suppose, for example, that the first proof was originally in the main text of an authoritative manuscript of the Ilāhiyya $t$, before the second proof, as a deleted part of chapter VIII.4, and that some copyist mistakenly overlooked its deletion marks and copied it in its present position, namely before the second proof, along with the rest of the chapter. In this perspective, we are entitled to think that the first proof was Avicenna's first unfinished account of the proof of the $\beta$ thesis, which he soon crossed out in favour of the second proof, but which remained under deletion marks in his autograph of the work, exposed to the risk of being incorporated into later copies of it, as it actually happened in part of the manuscript tradition presently known.

Alternatively, we can suppose that the first proof was originally written in the margin of an ancient and valuable manuscript of the Ilähiyyāt, in proximity of the second proof and as a gloss of this latter, being later incorporated into the main text of the copy of this manuscript, not after the second proof but mistakenly before it. It cannot be excluded that the glossator at stake was Avicenna himself: in light of the authorial revisions that his writings underwent, we are

31 When applying this principle during the second proof, Avicenna significantly employs the expression "in its existence" in reference to that-ness, when this latter follows the quiddity. 
entitled to suppose that a marginal addition or clarification in his autograph of the Ilähiyyāt passed into a part of the manuscript tradition. On the other hand, we cannot rule out the agency of some very early "commentator" of his writings. Contrary to the current scholarly opinion according to which only Avicenna's Kitāb al-Ǐsāärät wa-l-tanbīhāt (Book of Pointers and Reminders) was commented upon in the first generations of scholars after Avicenna, incipient research is bringing to light early exegetical practices regarding the Šif $\bar{a}{ }^{3}{ }^{22}$ The Ilähiyyāt is a case in point: the most ancient known manuscript of the work (Najaf, Maktabat al-Imām Amīr al-Mu'minīn, 3070, copied in 1102-1103) already shows traces of exegesis inserted into the text ("external commentary", šarh hāariğ), which are not dissimilar in pattern from the explanation reported by al-Lawkarī. ${ }^{33}$ Similar exegetical concerns about the Ilāhiyyāt can be found in works of the first decades of the 12 th century. ${ }^{34}$

It is hard to decide which alternative is the correct one. Much depends on how the beginning of the first proof should be read, i.e. whether "We say" as in the Cairo edition (a situation compatible with the first scenario envisaged above), or "Its/His meaning" as in al-Lawkarī (a reading which favours the second scenario). Text 4 points towards the second direction, suggesting that the first proof of thesis $\beta$ was a later explanation of Avicenna's original text. More specifically, the Bayān al-haqq looks to witness a stage of the transmission of the Ilahhiyyāt in which the marginal annotation had already been inserted into the manuscript (or manuscripts) of the Ilāhiyyāt consulted by al-Lawkarī,

32 Di Vincenzo 2018.

33 Foll. $67^{\mathrm{r}}$, lin. 20-68 , lin. 33. The passage, regarding Ilāhiyyāt III.1O, is marked by intahà signs at the beginning and at the end: it is named "external commentary" (šarh hāariğ) at the beginning, and it ends with the expression "It goes back to the text" ('áda ilà al$a s ̧ l)$. Within it, Avicenna's text is commented in lemmatic form, with lemmata signaled by expressions like "With his statement (...) he [Avicenna] indicates (...)" (qawluhū (...) yuširu bihī ilà (...)), "This is the meaning of his statement" ( fa-hādā mánà qawlihī), and "He says" ( $f a-q \bar{a} l a$, or $q \bar{a} l a)$. In another place (fol. 6ov), the manuscript reports what looks like a gloss to the Cairo text of Ilähiyyāt II.3, also included within intahà signs, which starts with "I rather say (...)" (bal aqūlu): this expression is similar to the "We rather say" (bal $n a q \bar{u}(u)$ that is found at the beginning of the first proof of thesis $\beta$ in some manuscripts of Ilāhiyyāt viII.4, as mentioned above. I am grateful to Silvia Di Vincenzo and Stefano Di Pietrantonio, cooperators of the project PhiBor 2014-2019, for having brought these passages to my attention. Silvia Di Vincenzo is planning to publish the text of the former passage in a forthcoming publication.

34 In Rukn al-Dīn Ibn al-Malāḥimī (d. 1141)'s Tuhfat al-mutakallimīn fì l-radd 'alā l-falāsifa (Gift for the Theologians in Refutation of the Philosophers), the three explicit quotations of the Šifä’' come from the Ilāhiyyāt. One of them (p. $12017 \mathrm{ff}$.) deals with a criticism that a later scholar addresses to Avicenna about an alleged inconsistency of his argumentation in Ilähiyyāt IX.2 (p. 389.4 ff.; p. 388.8 ff.). 
but still preserved clear traces of its original status of marginal gloss. ${ }^{35}$ In this perspective, the aforementioned passage of the Bayān al-haqq deserves to be attentively considered as a possible piece of evidence for the ongoing dossier of Avicenna's authorial revisions of the Ilähiyyāt or of the early exegesis of this work.

Whatever the case, the absence of the first proof in the Latin translation (XII century) and in other early manuscripts of the Ilāhiyyāt might reveal, rather than a mechanical loss of a passage in these testimonia, a stage of the history of our text that antecedes the undesired presence in it of the first proof, either as a deleted part of the text, or as a marginale of it.

\subsection{Avicenna and His School: The Evidence of Chapter VIII.4}

What we can infer from the above analysis is that chapter VIII.4 of the Ilähiyyant, as we read it in the Cairo edition, preserves traces of school discussions. The evidence analyzed in section 2 shows that Avicenna possibly wrote a part of this chapter having his disciples in mind, if not physically in front of him, to whom he addressed his self-explanations in a didactic and dialogical context. Section 3 documents that these same disciples might have continued to unravel the difficulties of this key-chapter of the master's metaphysics also on their own, without the master or after his death. In fact, we are informed that the issue of God's essence, the central topic of chapter viII.4, was debated within Avicenna's circle. ${ }^{36}$ If this hypothesis should be corroborated by future research, one could envisage an ideal three-layer structure of the text of the

35 The alternative hypothesis that al-Lawkarī was reading the marginal annotation as a real marginale in his own manuscript of the Ilāhiyyāt and that he misplaced it in the Bayān al-haqq precisely where it is now found in other manuscripts of Avicenna's work, sounds unlikely. Even less likely is the hypothesis that al-Lawkarī himself originated the explanation at stake, thus influencing an entire branch of the later manuscript tradition of the Ilähiyyāt: since the Bayān al-haqq is a free paraphrase of the Šifä', in which the text of Avicenna's work is frequently adapted rather than verbatim copied, he could have made and inserted this gloss with respect to Ilähiyyāt viII.4 without any need of noticing that this was an explanation made by someone (in fact, by him).

36 The aforementioned Bahmanyār Ibn al-Marzubān, in the Kitāb al-Tahṣil, p. 570.11-13, holds at the same time that God has no quiddity (mähiyya) and that God's essence (haqiqqa) is "what is without name" (or that God has an essence without name, Janssens 2003, p. 191, n. 42; Janssens notices a parallel of this contention in Avicenna's Talīqät, Annotations, Ibn Sīnā 1974, p. 185.15-16, and 185.26). For the issues revolving around "necessary-ness" (wāğibiyya) as a possible way of describing God's essence in Avicenna's Mubāhatāāt (Discussions) and in the later Avicennian tradition, see Zamboni 2020 and the bibliography quoted therein. It is worth noticing that the Mubāhatāat contain a "synopsis" (talhiṣ̂) of the Ilāhiyyāt ascribed to Bahmanyār (see Ibn Sīnā 1992, §§799-817; Reisman 2002, p. 43, and Appendix F, I.B.c.2, p. 293; II, p. 300). This synopsis randomly covers excerpts of the 
Ilāhiyyāt in this chapter: i) the original text of Avicenna, with some of his selfexplanations (those at the first plural person, surely authorial); ii) the text of Avicenna with some superadded self-explanations by Avicenna (those at the first singular person, equally authorial), as a follow-up of school discussions; iii) the text of Avicenna with the self-explanations of the master plus the glosses of the disciples (like the possible non-authorial explanation reported by alLawkarī), as the result of ensuing debates. This glimpse of Avicenna as a master "within his classroom", and of his teaching as a peer-reviewed process, in chapter VIII.4 of the Ilähiyyāt alerts us of the possibility of finding traces of this same synergy also elsewhere in Avicenna's masterpiece, and helps clarifying the dynamics at work within the so-called "school" of Avicenna and the role of this latter as primus inter pares among his disciples. ${ }^{37}$

The articulated scenario emerging from the previous pages recommends some prudence as to the doctrinal tenets that we can surely ascribe to Avicenna in Ilähiyyāt VIII.4. As we have seen, the argumentative structure of chapter vilI.4 resembles at times that of Chinese boxes, in which different theses coexist, intersperse, and replace one another. In this multifarious context, the NEOB thesis, crucial for the present purposes, makes a fugacious, unexpected, and transient apparition, within a chapter which focuses beforehand on theses $\beta$ and $\gamma$ and switches immediately afterwards to the theologia negativa resulting from the ЕОв thesis. The argumentative path leading to this abrupt and unforeseen меов thesis is affected by a textual uncertainty which requires careful philological investigation, since exegetical efforts by Avicenna's immediate interlocutors or later readers might have been incorporated into the text of the chapter as we read it in the current Cairo edition. The NEOB thesis itself is commented a posteriori by Avicenna in a very special and unprecedented way, i.e. by means of clarifications at the first singular person, which accrue over his more usual explanations at the first plural person, anomalously frequent in chapter VIII.4. The coexistence in chapter VIII.4 of the self-explanations that occur only here in the entire Ilāhiyyatt, namely those at the first singular person in application to the NEOB thesis, with Avicenna's standard modes of self-explanation in the work, sheds some suspicious light on the former as possible later authorial interventions. In this situation, any clear-cut statement about the precise extent of Avicenna's recourse to the Liber de causis in the NEOB thesis of chapter VIII.4 of the Ilähiyyāt should be advanced cautiously.

Ilāhiyyāt, which span from chapter I.2, p. 13.12, until chapter viII.4, p. 346.12, exactly the point of chapter viII.4 where the first proof of the $\beta$ thesis starts.

On the circle of scholars who gathered around Avicenna, see al-Rahim 2018. 
The alleged recourse to the Liber de causis in chapter VIII.4 of Avicenna's Ilāhiyya $\bar{t}$ is a paradigmatic exemplification of two main aspects of Avicenna's philosophy: on the one hand, his comprehensive and original use of sources; on the other hand, the vicissitudes of composition and transmission of his philosophical works (in the present case, of his main work on metaphysics). In the former respect, Avicenna's possible citation of proposition VIII[IX] of the Liber de causis enters in a wider and full-fledged doctrinal system in which the clear-cut thesis possibly drawn from the Liber de causis (God does not have any essence at all and is only existence) coexists on equal foot with more nuanced and originally Avicennian theses (God does not have any essence other than existence, or God does not have any essence other than necessary existence) and is inserted into an anti-Platonic setting of Aristotelian origin. In the latter respect, significant textual elements, which only a sort of "stratigraphic" philological analysis is able to disclose, hint at the possibility that this pivotal chapter of the Ilähiyya $\bar{t}$, as we read it in the current edition, might represent the cooperative result of a living network of thinkers: in this kind of "dialogical" setting, the doctrines of the Šayh al-ra'šs are explained by him and commented upon by his school, and explanatory remarks are added both by Avicenna himself to his own exposition, and by the disciples to their master's statements.

The precise channels and ways of Avicenna's reception of the Neoplatonic sources in general, and of the Liber de causis in particular, have to be properly assessed. More specifically, once it is assumed that he did make recourse to the Liber de causis, we should ask whether he accessed this work directly or indirectly: if his access was direct, it remains to be ascertained in which form it occurred; if it was indirect, through which mediation it took place. ${ }^{38}$ On the other hand, in a complementary way, the text of Avicenna's Ilāhiyyāt upon which we can test the amount and degree of his recourse to the Liber de causis is still imperfectly known and is far from being ultimately established.

For the time being, it can be confidently stated that, if Ilähiyyät VIII.4 is really the prototype of Avicenna's dependence on the Liber de causis, then the entire issue of Avicenna's recourse to this important specimen of the Arabic Neoplatonism deserves to be placed under the rubric of his "assimilation" of the received philosophical tradition, as an ingredient of his aspiration towards

38 Wakelnig 2007, p. 457-469, for example, documents that the version of the Liber de causis used by Abū l-Ḥasan al-Āmirī (d. 992) is longer than the current one. For some hints of Avicenna's likely use of a version of the Liber de causis different from the one edited by Thillet, Oudaimah 2001-2002, see above, n. 7 . 
a more encompassing and more personal system of thought. Conversely, the topic of Avicenna's reliance on the Liber de causis cannot be properly faced without addressing the issue of the possible multiple recensions of Avicenna's works, and of the impact of the members of Avicenna's school on the editing of the works of the master, an issue that recent scholarship on Avicenna is bringing to the fore. ${ }^{39}$

\section{Acknowledgements}

I am very grateful to Dragos Calma and all the participants of the conference Les traditions grecques, arabes et latines des Éléments de Théologie et du Livre des causes, organized by Dragos Calma and Marc Geoffroy, with the assistance of Olivier Boulnois and Philippe Hoffmann (Paris, April 2016), for the invaluable remarks on a first draft of the present paper. Research related to this paper was also presented in Scuola Normale Superiore di Pisa in June 2016, in the framework of a workshop held by Rüdiger Arnzen ("On the Editorial Technique of Medieval Arabic Philosophical Texts"), to whom my sincere thanks go for the useful feedback received on that occasion, as well as on the final draft of the present article. I wish to pay to the late Marc Geoffroy, organizer of the aforementioned conference and generous inspirer of my research on countless occasions, a heartfelt tribute of professional esteem and personal gratitude.

\section{Bibliography}

\section{Manuscripts}

Leiden, Universiteitsbibliotheek

Golius 209.

Or. 4.

Najaf, Maktabat al-Imām Amīr al-Mu'minīn, 3070.

Oxford, Bodleian Library, Pococke

110.

125 .

Rasht, Kitābhānah-i Millī, 37 .

Tehran, Kitābhānah-i

Millī Malik, 1085.

39 Bertolacci 2012b; Bertolacci 2017; Di Vincenzo 2017. 
Dāniškādah-i Ilāhiyyāt-i Dānišgāh-i Tihrān 695D.

Mağlis-i Šūrā-yi Islāmī 4081.

Markazī-yi Dānišgāh-i Tihrān 25o.

\section{Primary Sources}

Abū l-'Abbās Faḍl Ibn Muḥammad al-Lawkarī, Bayān al-Haqq bi-ḍamān al-ṣidq (Clarification of the Truth with the Guarantee of the Veracity). Al-Mantiq 1, al-Madhal, I. Dībāğī (ed.), Tehran 1986 (also published in Islamic Thought. Series of Texts Studies and Translations. II, Kuala Lampur, ISTAC [International Institute of Islamic Thought and Civilizations], 1993-1994).

Abū l-Abbās Faḍl Ibn Muḥammad al-Lawkarī, Bayān al-Ḥaqq bi-ḍamān al-ṣidq. AlQism al-ilāhī, I. Dībāḡì (ed.), Tehran 1995 (also published in Islamic Thought. Series of Texts Studies and Translations. II, Kuala Lampur, ISTAC [International Institute of Islamic Thought and Civilizations], n.d.).

Abū l-Ḥasan Bahmanyār Ibn-al-Marzubān, Kitāb al-Taḥ̣̂̄l, M. Muṭahharī (ed.), Tehran 1349/1971; 2nd printing, Tehran, Intišārāt-i Dānišgāh-yi Tihrān, 1375Hš/1996.

Al-Aflāțūniyya al-muhdața 'inda l-Arab, ed. 'A. Badawī, Pseudo-Aristotle, Cairo, Wakālat al-Mațbū'āt, 1955; third edition, 1977, p. 1-33.

(Avicenna) Ibn Sīnā, Al-Šifā̄, al-Ilāhiyyāt (ı), ed. Ğ.Š. Qanawatī, S. Zāyid; Al-Šifāà, alIlāhiyyāt (2), ed. M.Y. Mūsā, S. Dunyā, S. Zāyid, Cairo, al-Hay’a al-āmma li-šu’ūn al-mațābic al-amīriyya, 196o.

(Avicenna) Ibn Sīnā, Al-Šifä̀), al-Manțiq, al-Burhān, ed. A. 'Afïfì, Cairo, al-Mațbaca alamīiyya 1956.

(Avicenna) Ibn Sīnā, Al-Šifā', al-Ṭabīiyyyāt, al-Nabāt, ed. 'A. Muntașir, S. Zāyid, 'A. Ismāōìl, al-Hay’a al-āmma li-šu'ūn al-mațābic al-amīriyya, Cairo 1965.

(Avicenna) Ibn Sīnā, Libro della guarigione. Le cose divine di Avicenna (Ibn Sīnā), ed. A. Bertolacci, Torino, UTET.

(Avicenna) Ibn Sīnā, The Metaphysics of the Šifä. Facsimile Edition of Ms Malek Library (Tehran) 1085, Dated 509H/1115. With Introductions in English and Persian by A. Bertolacci and G. Dadkhah, Mazda Publishers, Costa Mesa (CA) 2019.

(Avicenna) Ibn Sīnā, Ta līqāt, ed. 'A. Badawī, Al-Hay’a al-miṣriyya al-'āmma li-l-kitāb, Cairo, 1973.

(Avicenna) Ibn Sīnā, Mubāḥatāat, ed. M. Bīdārfar, Maṭba'at-i Amīr, Qom, 1992.

Liber de causis: O. Bardenhewer, Die pseudoaristotelische Schrift Ueber das reine Gute bekannt unter dem Namen Liber de causis, Freiburg im Breisgau, Herder'sche Verlag, 1882 [repr. Minerva, Frankfurt am Main], 1961.

Taylor, R.C., The Liber de causis (kalām fĩ maḥ̣ al-khair): A Study of Medieval Neoplatonism, Ph.D. Dissertation, University of Toronto, 1981.

P. Thillet, S. Oudaimah, "Proclus Arabe. Un nouveau Liber de causis?", in Bulletin d'études orientales, 53-54 (2001-2002), p. 293-367. 
Rukn al-Dīn Ibn al-Malāḥimī al-Khwārazmī, Tuḥfat al-mutakallimīn fì l-radd 'alā lfalāsifa, ed. Hasan Ansari, Wilferd Madelung, Tehran-Berlin, Iranian Institute of Philosophy-Institute of Islamic Studies Free University of Berlin, 2008.

PhiBor (2014-2019), ERC FP7 Advanced Grant 2013 "Philosophy on the Border of Civilizations and Intellectual Endeavours: Towards a Critical Edition of the Metaphysics (Ilahiyyat of Kitab al-Shifa') of Avicenna (Ibn Sina)" (PhiBor), Scuola Normale Superiore di Pisa, IMT School For Advanced Studies, Lucca, http://www.avicennaproject .eu/.

\section{Secondary Sources}

Bertolacci, A. (2004), "The Reception of Book B (Beta) of Aristotle's Metaphysics in the Ilāhiyyāt of Avicenna's Kitāb al-Šifā̄”, in J. McGinnis, with the assistance of D.C. Reisman (eds), Interpreting Avicenna: Science and Philosophy in Medieval Islam. Proceedings of the Second Conference of the Avicenna Study Group, Leiden / Boston, Brill, p. 157-174.

Bertolacci, A. (2006), The Reception of Aristotle's Metaphysics in Avicenna's Kitāb alŠifā': A Milestone of Western Metaphysical Thought, Leiden / Boston, Brill.

Bertolacci, A. (2007): see Avicenna.

Bertolacci, A. (2012), "The Distinction of Essence and Existence in Avicenna's Metaphysics: The Text and Its Context", in F. Opwis, D.C. Reisman (eds), Islamic Philosophy, Science, Culture, and Religion: Studies in Honor of Dimitri Gutas, Leiden / Boston, Brill, p. 257-288.

Bertolacci, A. (2012a), “A Hidden Hapax Legomenon in Avicenna's Metaphysics: Considerations on the Use of Anniyya and Ayyizya in the Ilāhiyyāt of the Kitāb al-Šifā", in A.M.I. van Oppenraay, with the collaboration of R. Fontaine (eds), The Letter before the Spirit. The Importance of Text Editions for the Study of the Reception of Aristotle, Leiden / Boston, Brill, p. 289-309.

Bertolacci, A. (2012b), "How Many Recensions of Avicenna's Kitāb al-Šifä’?", in Oriens, 40.2, p. 275-303.

Bertolacci, A. (2017), "The Latin Translation and the Original Version of the Ilāhiyyāt (Science of Divine Things) of Avicenna's Kitāb al-Šifā", in Documenti e studi sulla tradizione filosofica medievale, 28, p. 481-514

Bertolacci, A. (2017a), "Is God a Substance According to Avicenna?", paper presented at the International Conference of the Aquinas and the Arabs International Working Group, Creation and Artifice in Medieval Theories of Causality, The Warburg Institute, University of London, 1-2 June 2017 (org. C. Burnett, R. Taylor).

Bertolacci, A., Dadkhah, G. (2019): see Avicenna 2007.

D’Ancona, C. (1995), Recherches sur le Liber de causis, Paris, Vrin.

D'Ancona, C. (2000), "Avicenna and the Liber de causis: A Contribution to the Dossier", in Revista Española de Filosofía Medieval 7, p. 95-114. 
De Haan, D. (2020), Necessary Existence and the Doctrine of Being in Avicenna's Metaphysics of the Healing, Leiden-Boston, Brill.

Di Vincenzo S. (2017), "Is There a Versio Vulgata of Avicenna's Kitāa al-Šifǟ? On the Hypothesis of a Double Recensio of Kitāb al-Madhal", in Documenti e studi sulla tradizione filosofica medievale, 28, p. 29-70.

Di Vincenzo, S. (2018), "Early Exegetical Practice on Avicenna's Šifā’: Fahr al-Dīn alRāzī's Marginalia to Logic", in Arabic Sciences and Philosophy, 28.1, p. 31-66

Endress, G., Gutas, D. (eds) (2002), A Greek and Arabic Lexicon: Materials for a Dictionary of the Mediceval Translations from Greek into Arabic, vol. I, Leiden, Brill.

Janos, D. (2020), Avicenna on the Ontology of Pure Quiddity, Berlin, De Gruyter.

Janssens, J. (2003) "Bahmanyâr ibn Marzubân: a faithful disciple of Ibn Sînâ?", in D.C. Reisman with the assistance of A.H. Al-Rahim (eds), Before and after Avicenna: Proceedings of the First Conference of the Avicenna Study Group, Leiden, Brill, p. 177197.

Janssens, J. (2012), "Al-Lawkarī’s Reception of Ibn Sīnā’s Ilāhiyyāt", in D.N. Hasse, A. Bertolacci (eds), The Arabic, Hebrew and Latin Reception of Avicenna's Metaphysics. Proceedings of the Conference held at Villa Vigoni (Menaggio, Como), 2-6 July 20o8, Berlin, De Gruyter, p. 7-26.

Leinkauf, T. (2002), "Die Bestimmung des höchsten Prinzips als reines Sein-(Porphyrios), Victorinus, Boethius", in M. Erler, Th. Kobusch (eds), Metaphysik und Religion. Zur Signatur spätaniken Denkens, München-Leipzig, De Gruyter, p. 63-97.

Marcotte, R.D. (2006), "Preliminary Notes on the Life and Work of Abū l-'Abbās alLawkarī (d. ca. 517H/1123)", in Anaquel de Estudios Árabes 17, p. 133-157.

al-Rahim, A.H. (2018), The Creation of Philosophical Tradition. Biography and the Reception of Avicenna's Philosophy from the Eleventh to the Fourteenth Century A.D., Wiesbaden, Harrasowitz.

Reisman, D.C. (2002), The Making of the Avicennan Tradition: The Transmission, Contents, and Structure of Ibn Sinnàs al-Mubāḥatāt (The Discussions), Brill, Leiden.

Serra, G. (1975), “Alcune osservazioni sulle traduzioni dall' arabo in ebraico e in Iatino del De generatione et corruptione di Aristotele e dello pseudo-aristotelico Liber de Causis", in Scritti in onore di Carlo Diana, Bologna, Patron, p. 385-433.

Spallino, P., Panzeca, I. (2019), Il calamo dell'esistenza. La corrispondenza epistolare tra Șadr al-Dīn al Qūnawì e Nașìr al-Dīn al-Ṭūsì. Cura e traduzione dall' arabo di Patrizia Spallino e dal persiano di I. Panzeca, FIDEM, Barcelona-Roma.

Taylor, R. (2020), "Contextualizing the Kalām fı maḥ̣ al-khair / Liber de causis", in D. Calma (ed.), Reading Proclus and the Book of Causes, Volume 2. Translations and Acculturations, Leiden, Brill, p. 211-232.

Wakelnig, E. (2007), "Al-Āmirī's paraphrase of the Proclean Elements of Theology. A search for possible sources and parallel texts", in C. D'Ancona (ed.), The Libraries of the Neoplatonists, Leiden, Brill, p. 457-469. 
Wisnovsky, R. (2005), "Avicenna and the Avicennian Tradition”, in P. Adamson, R. Taylor (eds), The Cambridge Companion to Arabic Philosophy, Cambridge, Cambridge University Press, p. 92-136.

Zamboni, F.O. (2020), “Is Existence One or Manifold? Avicenna's Early Interpreters on the Modulation of Existence (Taškīkal-wuğūd)", in Documenti e studi sulla tradizione filosofica medievale, 31, p. 121-150. 